\title{
Summary of Training Workshop on the Use of NASA tools for Coastal Resource Management in the Gulf of Mexico
}

Conducted in Xalapa, Veracruz, Mexico, March 10-11, 2009

Prepared by Pacific Northwest National Laboratory for NASA Stennis Space Center under contract\# AGRNNS08AA91I
C. Judd
T.C. Gulbransen

K.S. Judd

R.M. Thom

March 2009

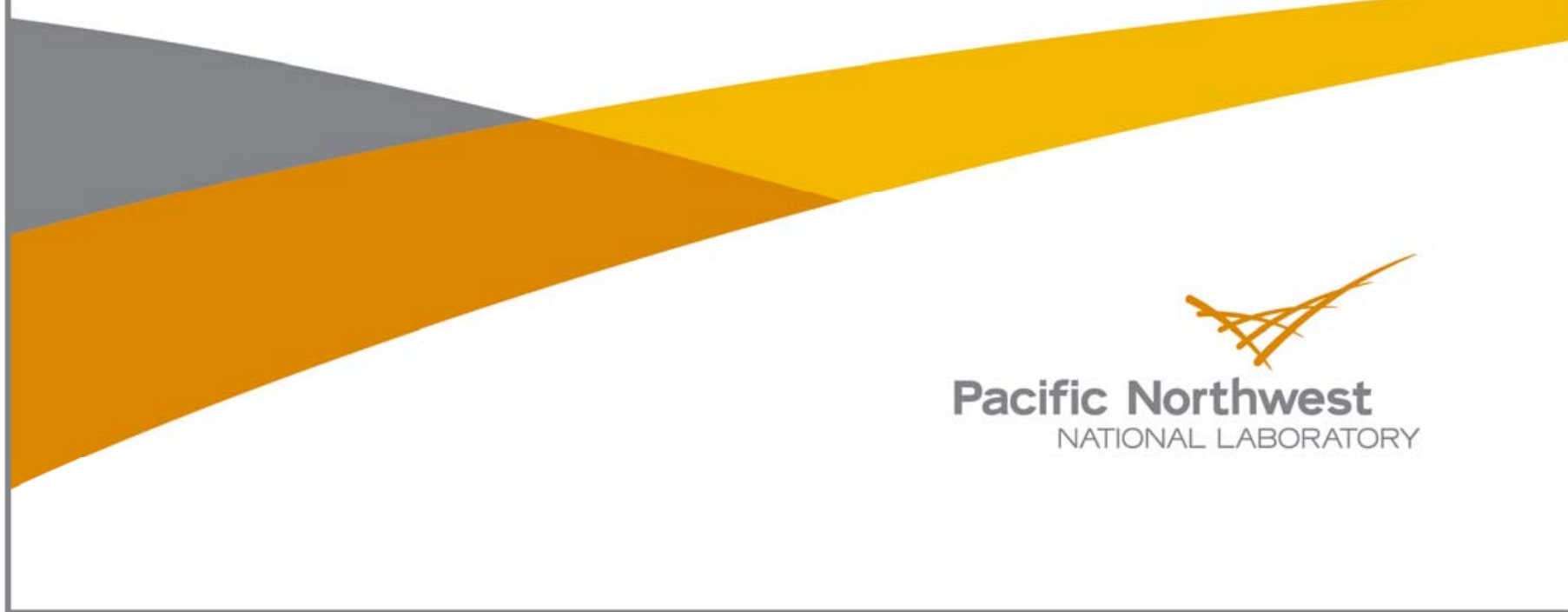




\title{
DISCLAIMER
}

This report was prepared as an account of work sponsored by an agency of the United States Government. Neither the United States Government nor any agency thereof, nor Battelle Memorial Institute, nor any of their employees, makes any warranty, express or implied, or assumes any legal liability or responsibility for the accuracy, completeness, or usefulness of any information, apparatus, product, or process disclosed, or represents that its use would not infringe privately owned rights. Reference herein to any specific commercial product, process, or service by trade name, trademark, manufacturer, or otherwise does not necessarily constitute or imply its endorsement, recommendation, or favoring by the United States Government or any agency thereof, or Battelle Memorial Institute. The views and opinions of authors expressed herein do not necessarily state or reflect those of the United States Government or any agency thereof.

\author{
PACIFIC NORTHWEST NATIONAL LABORATORY \\ operated by \\ BATTELLE \\ for the \\ UNITED STATES DEPARTMENT OF ENERGY \\ under Contract DE-AC05-76RL01830 \\ Printed in the United States of America \\ Available to DOE and DOE contractors from the \\ Office of Scientific and Technical Information, \\ P.0. Box 62, Oak Ridge, TN 37831-0062; \\ ph: (865) 576-8401 \\ fax: (865) 576-5728 \\ email: reports@adonis.osti.gov
}

Available to the public from the National Technical Information Service,

U.S. Department of Commerce, 5285 Port Royal Rd., Springfield, VA 22161

ph: (800) 553-6847

fax: (703) 605-6900

email: orders@ntis.fedworld.gov

online ordering: http://www.ntis.gov/ordering.htm

This document was printed on recycled paper. 


\section{Summary of Training Workshop on the Use of NASA tools for Coastal Resource Management in the Gulf of Mexico Conducted in Xalapa, Veracruz, Mexico, March 10-11,}

Prepared by Pacific Northwest National Laboratory

for NASA Stennis Space Center

under contract\# AGRNNS08AA91I

C Judd

TC Gulbransen

KS Judd

RM Thom

March 2009 


\section{Contents}

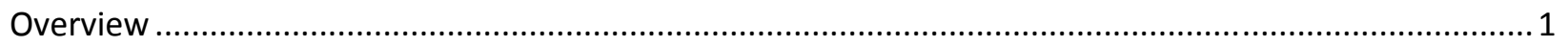

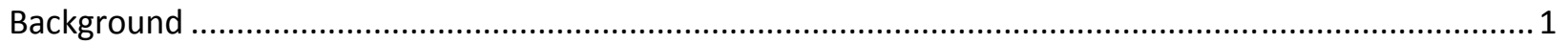

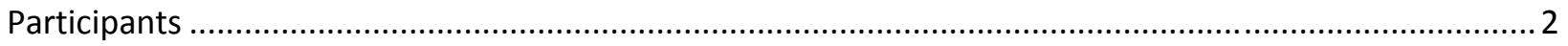

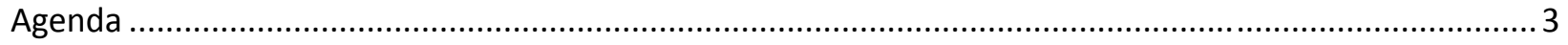

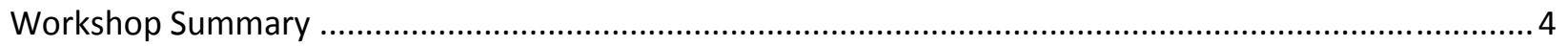

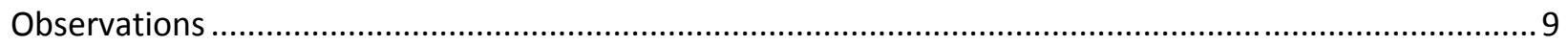

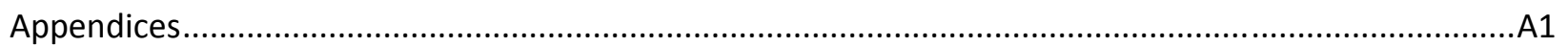




\section{Overview}

A two-day training workshop was held in Xalapa, Mexico from March 10-11 2009, titled "Use of NASA tools for Coastal Resource Management in the Gulf of Mexico," with the goal of training end users from the southern Gulf of Mexico states of Campeche and Veracruz in the use of tools to support coastal resource management decision-making. The workshop was held at the computer laboratory of the Institute de Ecologia, A.C. (INECOL), which is a research center of the Mexican National Science and Technology Commission (CONACYT).

The specific objectives of the workshop were to:

1. Review the ecological conceptual models developed by Mexican colleagues to date.

2. Understand how to use Gulf of Mexico Regional Collaborative (GoMRC) and Coastal On-line Assessment and Synthesis Tool (COAST) applications for coastal resource monitoring and selecting sites for restoration.

3. Define next steps regarding development of the tools, their application and continued utility to end users in Mexico.

The workshop was led by Battelle and was conducted primarily in Spanish.

\section{Background}

Prior to the workshop, the Battelle team had several engagements with potential end users in Mexico. These included:

- A kick-off web/teleconference in November to provide an introduction to the project and an overview of the COAST and GoMRC toolset. Over 30 representatives of various institutions in Veracruz, Campeche and Mexico City participated.

- A conference call in early December with a subset of scientists from the first call interested in learning more about the conceptual model development process.

- One-on-one conference calls in January with two scientists to prepare for a conceptual model workshop at Battelle's Marine Sciences Laboratory.

- A conceptual model workshop at Battelle's Marine Sciences Laboratory in Sequim, Washington with four visitors from Mexico. The purpose of this workshop was to review and finalize use cases and ecological conceptual models for mangroves in Los Petenes in Campeche and for seagrasses in the Parque Nacional Sistema Arrecifal Veracruz / Laguna Alvarado contiguous systems in Veracruz.

In the weeks between the working sessions described above, two separate teams of Mexican scientists worked collaboratively to develop conceptual models for mangrove habitat in Los Petenes region of Campeche and for coral reef habitat in the Coral Reef National Park System in Veracruz. A third team that was focused on seagrasses reviewed the existing GoMRC model and determined that with the exception of one or two additional locally relevant stressors (e.g. ballast water), the GoMRC model developed for Mobile Bay was appropriate for evaluating seagrass habitat in the Laguna Alvarado/Coral Reef National Park System as well. 


\section{Participants}

Thirteen end users from institutions in Mexico participated in the workshop. Three facilitators from Battelle traveled to Mexico for the workshop and Mr. Irigoyen-Lopez of Veracruz supported Battelle with local outreach and coordination. Participants from Mexico represented both Gulf coast states involved in the pilot project, Veracruz and Campeche, and a good mix of disciplines, including coastal scientists/researchers, organizations with coastal resource management and restoration responsibility, and policymakers. A complete list of participants is presented in the table below.

\begin{tabular}{|c|c|c|c|}
\hline & Name & Institution & Contact Information \\
\hline 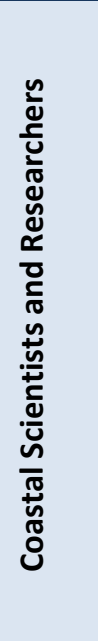 & $\begin{array}{l}\text { Ana Laura Lara } \\
\text { Dominguez } \\
\text { Margarita Gallegos } \\
\text { Martinez } \\
\text { Claudia Agraz Hernandez } \\
\text { Leon Rodrigo Gomez } \\
\text { Aguilar } \\
\text { Eduardo Sainz Hernandez } \\
\text { Oscar A Jimenez } \\
\text { Victor Manuel Vasquez } \\
\text { Reyes }\end{array}$ & $\begin{array}{l}\text { Institute of Ecology (INECOL) in } \\
\text { Veracruz, CONACYT } \\
\text { Universidad Autónoma } \\
\text { Metropolitana } \\
\text { EPOMEX/Universidad Autónoma de } \\
\text { Campeche } \\
\text { INECOL } \\
\text { INECOL } \\
\text { INECOL } \\
\text { INECOL }\end{array}$ & $\begin{array}{l}\text { Ana.lara@inecol.edu.mx } \\
\text { margalitita@gmail.com } \\
\text { hipocolito@gmail.com } \\
\text { leonrodrigogomez@gmail.com } \\
\text { eduardo.sainz@inecol.edu.mx } \\
\text { jorocio@hotmail.com } \\
\text { vicvasmx@yahoo.com }\end{array}$ \\
\hline 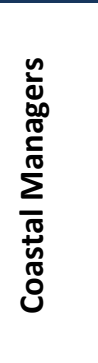 & $\begin{array}{l}\text { Ramon Martinez Ramon } \\
\text { Guadalupe Campos } \\
\text { Bautista }\end{array}$ & $\begin{array}{l}\text { Coral Reef National Park System of } \\
\text { Veracruz - National Commission of } \\
\text { Protected Areas } \\
\text { (CONANP/SEMARNAT) } \\
\text { Coral Reef National Park System } \\
\text { Veracruz Aquarium }\end{array}$ & $\begin{array}{l}\text { ilopez@conanp.gob.mx } \\
\text { rmr@conanp.gob.mx } \\
\underline{\text { marcaroja@acuariodeveracruz.com.mx }} \\
\underline{\text { lupiscampos@yahoo.com }}\end{array}$ \\
\hline 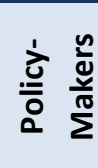 & $\begin{array}{l}\text { Victor Ladron de Guevara } \\
\text { Elda Castillo Zavaleta } \\
\text { Rosa Issel Castro Villareal }\end{array}$ & $\begin{array}{l}\text { Veracruz State Government } \\
\text { Veracruz State Government } \\
\text { Veracruz State Government }\end{array}$ & $\begin{array}{l}\text { vsobrino@sefiplan.gob.mx } \\
\text { eldacz@hotmail.com } \\
\text { rcastro@sefiplan.gob.mx }\end{array}$ \\
\hline $\begin{array}{l}\frac{n}{0} \\
\stackrel{5}{\pi} \\
\stackrel{5}{\frac{5}{5}} \\
\frac{\pi}{4}\end{array}$ & $\begin{array}{l}\text { Chaeli Judd } \\
\text { Ron Thom } \\
\text { Tom Gulbransen } \\
\text { Juan Manuel Irigoyen- } \\
\text { Lopez }\end{array}$ & $\begin{array}{l}\text { Battelle / PNNL } \\
\text { Battelle / PNNL } \\
\text { Battelle } \\
\text { Advisor to INECOL }\end{array}$ & $\begin{array}{l}\text { chaeli.judd@pnl.gov } \\
\text { ron.thom@pnl.gov } \\
\text { gulbran@battelle.org } \\
\text { imirigoyen@hotmail.com }\end{array}$ \\
\hline
\end{tabular}




\section{Agenda}

The workshop was organized around five sessions, as highlighted in the agenda below.

\begin{tabular}{|c|c|}
\hline Martes, 10 de marzo & Tuesday, March 10th \\
\hline Sección 1: Introducción 9:00 - 10:30 & Session 1: Introduction 9:00-10:30 \\
\hline 9:00 Bienvenida & 9:00 Welcome \\
\hline Dr. Jorge López-Portillo & Dr. Jorge López-Portillo \\
\hline Juan Manuel Irigoyen & Juan Manuel Irigoyen \\
\hline 9:15 Objetivos del taller & 9:15 Workshop Objectives \\
\hline Dr. Ron Thom, Chaeli Judd, Tom Gulbransen & Dr. Ron Thom, Chaeli Judd, Tom Gulbransen \\
\hline 9:30 Principios del manejo costero y & 9:30 Principles of Coastal Management \\
\hline restauración & Dr. Ron Thom \\
\hline Dr. Ron Thom & 11:00 Coffee break \\
\hline 11:00 Coffee break & \\
\hline Sección 2: Resumen del trabajo realizado 11:20- & Session 2: Review of work to date 11:20 -13:30 \\
\hline $13: 30$ & 11:30 Overview of work to date - Veracruz \\
\hline 11:30 Resumen del trabajo realizado a la fecha & Dra. Ana Laura Lara Dominguez \\
\hline de en Veracruz & Ramón Martínez Ramón \\
\hline Dra. Ana Laura Lara Dominguez & $12: 15$ Overview of work to date- Campeche \\
\hline Ramón Martínez Ramón & Dra. Claudia Agraz Hernández \\
\hline 12:15 Resumen del trabajo realizado a la fecha & Dra. Margarita Gallegos Martínez \\
\hline de en Campeche & 13:00 Conceptual Model \\
\hline Dra. Claudia Agraz Hernández & Panel of participants \\
\hline Dra. Margarita Gallegos Martínez & \\
\hline 13:00 Modelo Conceptual & \\
\hline Panel de participantes & \\
\hline Almuerzo 13:30 a 14:30 & Lunch $13: 30$ a $14: 30$ \\
\hline Sección 3: Entrenamiento 14:30 - 18:00 & Session 3: Training 14:30 - 18:00 \\
\hline 14:30 Resumen de GoMRC y COAST & 14:30 Overview of GoMRC and COAST \\
\hline Chaeli Judd & Chaeli Judd \\
\hline 15:00 Introducción a los Casos de Uso & 15:00 Introduction to Use Cases \\
\hline Chaeli Judd & Chaeli Judd \\
\hline 15:15 Primer Caso: Monitoreo Costero con & 15:15 Use Case 1: Coastal Monitoring with \\
\hline Conceptual Model Explorer, Noesis y COAST & Conceptual Model Explorer, Noesis and COAST \\
\hline 17:00 a 18:00 Grupo de trabajo & 17:00 a 18:00 Group discussion \\
\hline Miércoles, 11 de marzo & Wednesday, March 11th \\
\hline Sección 4: Entrenamiento & Session 4: Training \\
\hline 09:00 Segundo Caso: Restauración & 09:00 to $10: 30$ Use Case 2: Restoration \\
\hline
\end{tabular}




\begin{tabular}{|l|c|}
\hline \multicolumn{1}{|c|}{ Uso de Work Flow Explorer y CME Editor } & Use of Work Flow Explorer and CME Editor \\
10:30 Coffee Break & $10: 30$ Coffee Break \\
11:00 Continuación del segundo caso & $11: 00$ Continue second case \\
11:30 Grupo de trabajo & $11: 30$ Group discussion \\
Chaeli Judd and Tom Gulbransen & Chaeli Judd and Tom Gulbransen \\
& \\
Sección 5: Desarollo de un programa de monitoreo & Session 5: Developing a monitoring program based \\
con base en el modelo conceptual & on conceptual model \\
12:00 Discurso & $12: 00$ Discussion \\
Ron Thom & Ron Thom \\
& \\
Temas de seguimiento para el desarollo de las & Next steps for tool development and decision-making \\
herramientas y la toma de decisiones. & $13: 00-14: 00$ Group discussion \\
13:00-14:00 Grupo de trabajo & Tom Gulbransen \\
Tom Gulbransen & \\
\hline
\end{tabular}

\section{Workshop Summary}

Session 1: Introduction and Principles of Coastal Restoration

Juan Manuel Irigoyen welcomed the participants and Chaeli Judd reviewed the workshop objectives.

Dr. Ron Thom then gave a presentation on the Principles of Coastal Restoration. He reviewed a general framework for thinking about coastal restoration and elaborated on the role of conceptual models to establish a common understanding of the ecosystem. Dr. Thom also described a framework for prioritizing areas for restoration. (See Appendix A.) The presentation was very well received. Even the scientists who had participated in the workshop

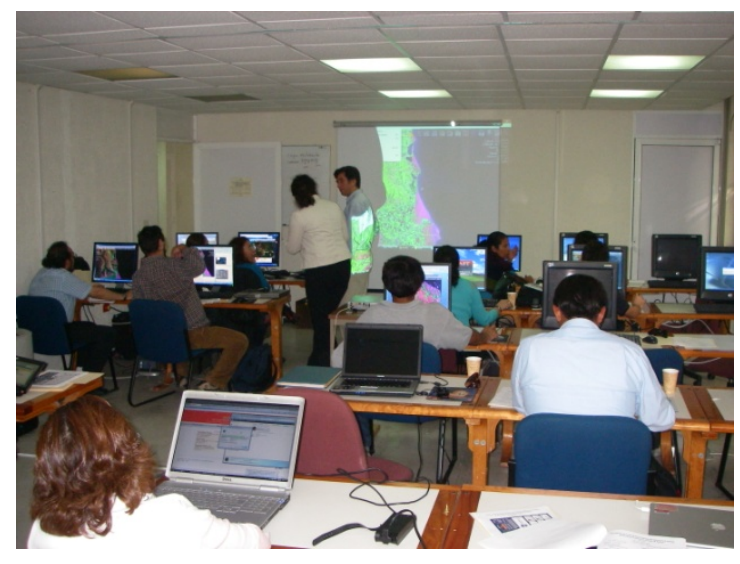
with Dr. Thom at Battelle's Marine Sciences Laboratory said they had a better understanding of the framework after this session.

\section{$\underline{\text { Session 2: Status of Conceptual Model Development }}$}

The purpose of this session was to provide the Mexican scientists with an opportunity to present their advances in the development of conceptual models for mangroves and coral reefs. As noted above, the scientists concerned with seagrasses gave the existing GoMRC model a thorough review and concluded that it was suitable for their analysis of seagrass habitat in Veracruz.

The first presentation on the mangrove conceptual model was delivered by Dr. Ana Laura Lara Dominguez and Dr. Claudia Agraz Hernandez. The scientists agreed upon a general conceptual 
model for mangrove habitat in Mexico. Dr. Lara led the presentation on the general model and described its specific applicability to Veracruz, reviewed available data, and defined optimal conditions associated with the controlling factors, such as salinity, temperature, and soil type. Dr. Agraz identified unique stressors that applied to the Campeche mangrove systems. The presentation is in Appendix B and the mangrove conceptual model as viewed in the Conceptual Model Explorer (CME) is found in Appendix C.

The second presentation on the coral reef conceptual model was delivered by Ramon Martinez Ramon of the Coral Reef National Park System in Veracruz. This team was still in the process of creating conceptual model at the time of the workshop. They were unable to participate in the conceptual model workshop in Sequim, WA, but through discussions with those who participated in that workshop, were able to initiate a model on their own. To date, this team had held meetings among key stakeholders, including from the Coral Reef National Park, INECOL, the Veracruz Aquarium, Navy, and Verarcruz State planners. They commented that the process of developing the conceptual model was very beneficial, since it was the first time that some of these stakeholders had sat down together to talk about these issues. The team commented that if this effort is successful at the National Park in Veracruz, it could also serve as a tool to support coastal management in National Parks across Mexico.

\section{Session 3: Use Case 1, Coastal Monitoring - GoMRC Overview and Training in COAST, Conceptual} Model Explorer and Noesis to meet coastal monitoring objectives

Chaeli Judd and Tom Gulbransen provided an overview of GoMRC and the tools available for data search, visualization and analysis. While some of the participants were already familiar with GoMRC, there were several new participants at the workshop who were seeing this material for the first time. Most materials were translated into Spanish prior to the workshop. (See presentation in Appendix A.)

The tools were demonstrated through a use case approach. The use cases aimed to give end users a sense for how the

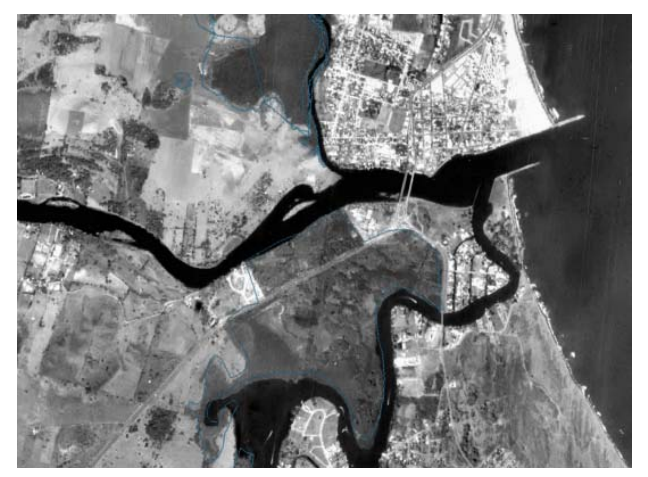
tools could be applied in the context of their day-to-day coastal management challenges. The first use case, which focused monitoring in coastal zones, was used to demonstrate the utility of COAST, the CME Viewer, and Noesis tools.

In COAST, users were trained in the use of its principal functions, including zoom, pan, how to show different layers, using plug-ins, adding Web Map Services (WMS), and adding shapefile or KML archives. (See COAST training guide as presented in Appendix F.) Prior to the workshop a set of demonstration data was compiled to be brought into COAST. This included Mangrove Classification of Veracruz from 2000 and 2006, and Landsat imagery from Campeche from 1973. In addition, a list of Mexican web mapping services were provided, and users experimented with adding different imagery. 
Using COAST, the participants were able to compare concurrently images of a mangrove area that was recently destroyed to a 2006 mangrove classification data layer for Veracruz. The trainers were able to highlight in COAST an area that the Mexican scientists did not know had been destroyed. This brought up additional requests for functionality in COAST.

In general, there was a lot of enthusiasm around COAST. Workshop participants found it to be user friendly.

In the CME Viewer, users trained how to use the toolbar to select objects of interest, how to show and hide relationships in the conceptual model and how to search for Information using the Noesis link.

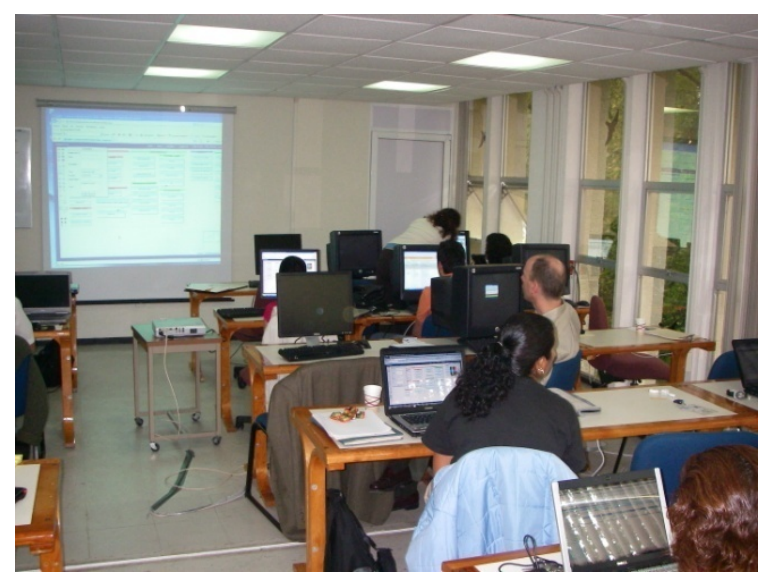

Session 4: Use Case 2, Restoration Prioritization - Training in Workflow Explorer and Conceptual Model Explorer Editor to meet restoration and conservation goals

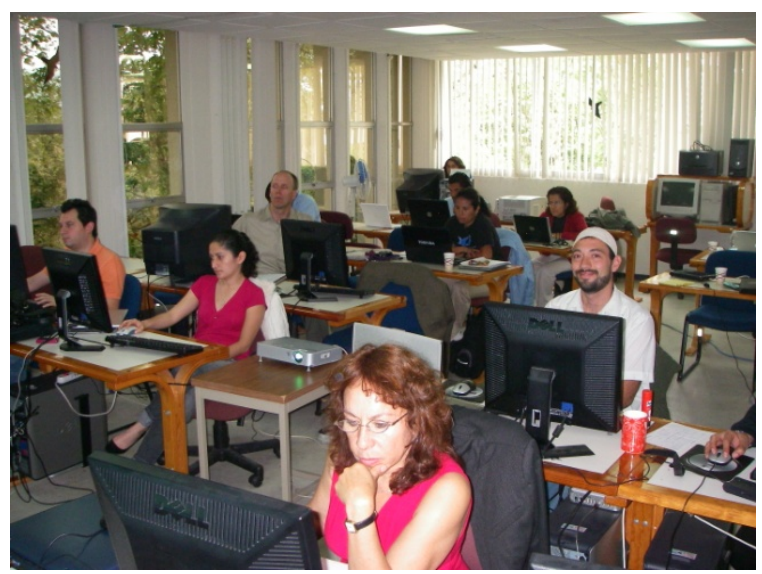

The second use case focused on use of tools within the Workflow Explorer which forms part of the CME. Users were taught the components of the tools and how they fit with previously described principles of ecosystem restoration, how to access these tools depending on their level of expertise and available software, and shown a demonstration of how these tools can be used together to assess habitat change and nearshore disturbance. In the coming weeks, the teams from Mexico and the U.S. will continue work on this use case, as some functionality improvements are completed. The basic functions of the CME Editor were demonstrated including, creation of new model, altering an existing model, and bookmarking.

\section{Session 5: Developing a monitoring program based on conceptual model}

Dr. Ron Thom presented a short session on how to use these developed conceptual models as the basis for developing a monitoring program. Conceptual models provide a way to communication between stakeholders with different interests as well as the public. Discussion of the uncertainties of relationships and feedbacks identifies areas of further research and monitoring. 


\section{Next steps and participant feedback}

At the end of the second day, the facilitators described the remaining planned adjustments to the tools that would be carried out by the project team and the group. These include further integration of Noesis search and COAST visualization tools and fixing some of the system errors encountered.

The facilitators then asked each participant for feedback on the two-day workshop and tools. Overall, the comments were positive and people were appreciative of the opportunity to participate. Users also provided valuable feedback on opportunities to make the tools more useful to them. Comments and suggestions are categorized by topic in the table below. Those in bold were emphasized by multiple users. The italicized notes include the facilitators responses or observations on lessons learned to help address the comment in future training sessions.

\section{General}

There was a general interest in getting more training. There was recognition that the tools have a lot of depth and are complex, and more time practicing the applications would be helpful.

Note: We should consider developing a formal training model for the toolset.

If the tools are determined to be useful in the Veracruz Coral Reef National Park, they may also be useful in other national parks.

Users would like to identify the Mexican partners on the GoMRC website and see the work completed under this project represented on the website.

\section{COAST}

\section{Interested in COAST but would like access to higher resolution imagery}

Note: It is important to emphasize to users that COAST does not limit access to higher resolution imagery.

Would like to see increased flexibility in the import of shapefiles and ability to display their attributes. Would like to digitize onto synthesis layers to be recalled later.

Would like to draw polygons and measure area similar to measuring distance of drawn line.

Would like to identify relevant layers based on geospatial corners.

Interested in ability to bring in different projections and image file types.

Current image products should be selectable from 2008 and ideally multi-years.

Interested in viewing movies in COAST, but disappointed at the lack of current data available.

Note: It is important to emphasize ability of users to point to data they need.

Very interested in visualizing local imagery with COAST. Brought in some additional imagery during the workshop. User had problems discovering what type of imagery was visible, and had to be re-projected to WGS-84.

Liked COAST. Recommend adding the ability to save a COAST session for a project, then when opening COAST again, having a blank slate (similar to .mxd documents in ArcGIS).

Add the ability in the layer manager to re-order the layers and change symbology.

Recommend some way of indicating which image is on top from the top toolbar.

Concerned that part of Mexico is cut-off.

One user said they would most likely use ArcGIS instead of COAST.

Conceptual Model Explorer

One user engaged in the use of the CME to create a conceptual model of the National Park believes it

provides a valuable means of bringing people together. This was the first time that some of the 
stakeholders have sat down together to discuss management of the coral reef system.

The conceptual models within the CME are basic for scientists but are understandable.

Would like to be able to easily show strength of a relationship between two elements (e.g. a stressor and a controlling factor), perhaps through width of line or color, by applying ranking conceptual model elements as having high, medium, or low impact.

Likes the CME tool, but concerned about oversimplification of models within CME.

Note: It is important to emphasize to users what CME's best uses are, and when it is not the appropriate tool.

The models can be simple or complex and are intended to provide a first step toward coming to a common understanding of how the ecology system of interest functions. The conceptual model alone is not intended to provide the basis for quantitative analysis.

Interested in ways that the conceptual model can be represented numerically and spatially. Can it be exported or incorporated into other software to look at some conditional statements?

Note: The Workflow Explorer provides this function.

Interested in applying the CME graphics interface to broader resource planning process. Is there a way to integrate CME with other tools (e.g. a SWOT analysis tool) that would help decision-makers make restoration prioritization decisions with the broader social context in mind?

Interested in bookmark feature of CME, and interested in application to prioritize restoration areas.

Noesis

Would like to have Noesis expand the repositories that it searchers to include data catalogs and journals that the Mexican scientists use. For example, CONABIO has a catalog of its data and documents pertinent to mangroves and coral reefs.

Would like the ontology to be searchable in English or Spanish. INECOL will translate ontology terms if a list can be provided to them.

Is it possible to allow users to add their own definitions?

Is it possible to add the coral reef conceptual model, when complete, to the ontology?

Finally, the group discussed next steps for applying the NASA tools to continue supporting their work. It was agreed that the Mexican scientists will:

- Provide a prioritized list of catalogues that might be included in Noesis searches

- Provide key words for English/Spanish interoperability in the ontology

- Continue working on the coral reef conceptual model and incorporate it into the CME.

The U.S. scientists will:

- Update the GoMRC website to reflect this bi-national collaboration and the work products developed

- Distribute conference materials and the summary report to participants.

Also, both the Mexican and U.S. scientists intend to continue working through the use cases in the weeks to come. That will involve:

- Matching stressors and habitat elements of the conceptual model with data assets

- Defining data needs from missing elements 
- Address data needs

- Assessing loss of habitat

- Assessing stress on habitats

- Identifying key areas for restoration or conservation.

\section{Observations}

The workshop on "Use of NASA Tools to Support Coastal Management in the Gulf of Mexico," and this project in general, have provided an excellent opportunity for bi-national collaboration in the Gulf of Mexico on the shared challenge of finding more effective ways to manage the Gulf's coastal resources. Such collaboration, training, and knowledge-sharing is fundamental to an ecosystembased approach to managing the Gulf's resources and has been identified by the Gulf of Mexico Alliance (GOMA) as an important activity.

The relationships developed through this six-month long project lay the ground work for future binational collaboration on coastal resource management. Two Mexican scientists have expressed in interest in collaborations with the GoMRC team on restoration and monitoring approaches, joint research projects, and on papers and presentations. They also have an interest in potentially placing post-docs at Battelle's Marine Sciences Laboratory.

Another important outcome of this activity has been creating an opportunity for improved collaboration among the science, coastal management, and policy community within the Mexican states of Campeche and Veracruz. One user from the Coral Reef National Park System in Verarcruz noted that the conceptual modeling exercise brought people together who had not collaborated in the past to address a set of common interests. Two other scientists who had been working relatively independently on mangrove monitoring and restoration in Campeche and Veracruz also began collaborating under this project, and agreed upon a general conceptual model for mangrove habitat in Mexico.

It should be noted that participants from Mexico invested a significant amount of their own time into this project, based on the expectation that the tools would support them with their ongoing coastal research and management work. They have delivered all of the products the Battelle team asked of them as partners in this project, and have been very engaged during each of our interactions. This is a testament to the value they see in these tools supporting their work.

Finally, two important indicators of the success of this effort are whether end users continue to: 1) expand applied use of these tools toward in-the-water issues and, 2) support future applications. At the March workshop, GoMRC and COAST achieved an important milestone in the level of applied use of the tool to respond to ongoing issues in natural resource management. The workshop not only helped reveal net changes in mangrove extent over time, it prompted workshop participants to go back to their offices in order to add additional local data to confirm the trend. It is conceivable that these resource managers and investigators will alter their approach to protective measures and field studies based on ad hoc discoveries made via GoMRC and COAST during the workshop. Integration of GoMRC and COAST is a function of software interoperability, data availability, user 
readiness and applicability to natural resource management issues. All four aspects of the project came together sufficiently and substantially enough improve natural resource managers' efforts. These successes also prompted indications from some of the Mexican collaborators that the tools could be used by seagrass experts to support work with Seagrass.net. 


\section{Appendices}

Appendix A: Overview of GoMRC and Principals of Coastal Management

Appendix B: Presentation on mangrove conceptual model development as applied in Veracruz

Appendix C: Mangrove Conceptual Model in the Conceptual Model Explorer

Appendix D: Presentation on Veracruz Coral Reef National Park System

Appendix E: Introduction to Use Cases

Appendix F: Use Case 1: Coastal Monitoring - Training guide for COAST, Conceptual Model Explorer, and Noesis

Appendix G: Use Case 2: Restoration Prioritization - Training for Workflow Explorer/ArcGIS

Prioritization Model and Conceptual Model Explorer Editor 